NBER WORKING PAPER SERIES

\title{
MODELING EXCHANGE-RATE PASSTHROUGH AFTER LARGE DEVALUATIONS
}

\author{
Ariel Burstein \\ Martin Eichenbaum \\ Sergio Rebelo \\ Working Paper 11638 \\ http://www.nber.org/papers/w11638
NATIONAL BUREAU OF ECONOMIC RESEARCH
1050 Massachusetts Avenue
Cambridge, MA 02138
September 2005

We thank Miles Kimball and an anonymous referee for their suggestions, and Pierpaolo Benigno, Mario Crucini, Andrew Levin, Carlos Vegh, Jessica Wachter, Ivan Werning, and Michael Woodford for their comments. We gratefully acknowledge financial support from the National Science Foundation and the Searle Foundation. The views expressed herein are those of the author(s) and do not necessarily reflect the views of the National Bureau of Economic Research.

(C2005 by Ariel Burstein, Martin Eichenbaum and Sergio Rebelo. All rights reserved. Short sections of text, not to exceed two paragraphs, may be quoted without explicit permission provided that full credit, including (C) notice, is given to the source. 
Modeling Exchange-Rate Passthrough After Large Devaluations

Ariel Burstein, Martin Eichenbaum and Sergio Rebelo

NBER Working Paper No. 11638

September 2005

JEL No. F31

\section{$\underline{\text { ABSTRACT }}$}

Large devaluations are generally associated with large declines in real exchange rates. We develop a model which embodies two complementary forces that account for the large declines in the real exchange rate that occur in the aftermath of large devaluations. The first force is sticky nontradablegoods prices. The second force is the impact of real shocks that often accompany large devaluations. We argue that sticky nontradable goods prices generally play an important role in explaining postdevaluation movements in real exchange rates. However, real shocks can sometimes be primary drivers of real exchange-rate movements.

Ariel Burstein

Bunche Hall 8365

Department of Economics

UCLA

Box 951477

Los Angeles, CA 90095-1477

arielb@econ.ucla.edu

Martin S. Eichenbaum

Department of Economics

Northwestern University

2003 Sheridan Road

Evanston, IL 60208

and NBER

eich@northwestern.edu
Sergio Rebelo

Kellogg Graduate School of Management

Northwestern University

Leverone Hall

Evanston, IL 60208-2001

and NBER

s-rebelo@ northwestern.edu 


\section{Introduction}

Large devaluations are generally associated with large declines in the real exchange rate (RER). In an earlier paper (Burstein, Eichenbaum, and Rebelo (2005)) we argue that the primary force causing these declines is a slow adjustment in the price of nontradable goods and services, not slow adjustment in the price of goods that are imported or exported. Our evidence suggests that the key puzzle about the post-devaluation behavior of inflation is, why do the prices of nontradable goods and services respond by so little in the aftermath of large devaluations? We develop a model that accounts for the negligible response of nontradable-goods prices in the aftermath of large devaluations.

Our model highlights two complementary forces that produce this result. The first force is sticky nontradable-goods prices. Instead of assuming that nontradablegoods prices are sticky, we develop conditions under which this phenomenon can emerge as an equilibrium outcome. The second force is the impact of real shocks associated with large devaluations that lead to a decline in the price of nontradable goods relative to traded goods. We study the importance of these two forces using three examples motivated by the devaluations in Korea (1997), Uruguay (2002), and the U.K. (1992).

In the Korean case, we find that to explain the large post-devaluation decline in the real exchange rate, we must allow for sticky nontradable-goods prices. Moreover, we argue that sticky nontradable-goods prices are sustainable as an equilibrium phenomenon. In the UK case, we find that the post-devaluation behavior of the real exchange rate can be explained solely as a result of sticky nontradable-goods prices. However, the Uruguayan case shows that it can be very misleading to assume that prices are sticky. In this case nontradable-goods

prices cannot be sustained as an equilibrium phenomenon and real shocks alone 
account for the post-devaluation real exchange-rate depreciation.

To model sticky nontradable-goods prices, we build on the many studies that analyze price stickiness in closed economies. The closed-economy literature identifies a class of models in which the gains from adjusting prices in response to changes in monetary policy are very small. These gains can be so modest that when there are small costs of changing prices, price stickiness is an equilibrium phenomenon. We incorporate into our model the key feature emphasized by Ball and Romer (1990), a relatively flat marginal cost curve. In addition, we adopt Kimball's (1995) assumption that the elasticity of demand for the output of a monopolistic producer is increasing in its price relative to the prices of its competitors goods.

There are two key differences between our analysis of sticky prices and the analogue closed-economy literature. First, we consider large changes in monetary policy instead of small changes. Second, we focus on open economies and identify key features of the model economy that play an important role in making sticky nontradable-goods prices sustainable as an equilibrium phenomenon.

To model the direct impact of real shocks on inflation and the real exchange rate, we build on the literature that models the mechanisms through which large devaluations lead to contractions in economic activity. ${ }^{1}$ A common feature of these models is that devaluations are associated with negative wealth effects. We capture these effects by considering two alternative real shocks, a decline in export demand and a reduction in net foreign assets. The first shock is drawn from the experience of countries like Uruguay, whose devaluations were precipitated by large declines in export demand associated with recessions in countries with whom they trade. The second shock captures in a direct, albeit in a brute force manner, the

\footnotetext{
${ }^{1}$ See, for example, Aghion, Bachetta, and Banerjee (2001); Burnside, Eichenbaum, and Rebelo (2001); Caballero and Krishnamurty (2001); Christiano, Gust, and Roldos (2004); and Neumeyer and Perri (2005).
} 
decline in real wealth that is a hallmark of contractionary devaluations. Arguably, we can think of the fall in real wealth as a proxy for the balance-sheet effects emphasized by some authors.

We suppose that the model economy is initially in a fixed exchange-rate regime and that there is then a change in monetary policy that leads to a large, permanent devaluation. To simplify, we assume that if there is a real shock, it occurs at the same time as the devaluation. To assess whether or not sticky nontradable-goods prices are an equilibrium, we calculate the post-devaluation equilibrium assuming that nontradable-goods prices are constant. We then compute the benefits to a nontradable-goods producer of deviating from a symmetric equilibrium by changing his price. In our model, the nontradable-goods sector is monopolistically competitive. Firms in this sector set local currency prices as a mark-up on nominal marginal cost, which is proportional to the nominal wage rate. So the benefit of deviating from a symmetric sticky price equilibrium depends critically on the response of the mark-up and nominal wages to a devaluation. Since we measure the benefits of deviating relative to an equilibrium in which prices are constant forever, we are adopting a conservative strategy for rationalizing sticky prices.

Our model open economy incorporates four assumptions that mute this response. First, the share of tradable goods in the consumer price index (CPI) is small. Second, there are domestic distribution costs associated with the sale of traded goods. Third, there is a low elasticity of the demand for exports. Fourth, there is a moderate elasticity of substitution between tradable and nontradable goods.

Section 2 describes our model. Section 3 presents our basic results. Section 4 discusses the role played by different features of our model in accounting for sticky nontradable-goods prices. Section 5 uses our model to discuss the possibility of an overvalued currency. Section 6 concludes. 


\section{The Model}

Here we present our model of a small open economy.

The Representative Household The household values streams of consumption services $\left(C_{t}\right)$, hours worked $\left(N_{t}\right)$, and real balances. Consumption services are produced by combining tradable $\left(C_{t}^{T}\right)$ and nontradable $\left(C_{t}^{N}\right)$ goods according to the CES technology

$$
C_{t}=\left[\nu^{\frac{1}{\rho}}\left(C_{t}^{T}\right)^{\frac{\rho-1}{\rho}}+(1-\nu)^{\frac{1}{\rho}}\left(C_{t}^{N}\right)^{\frac{\rho-1}{\rho}}\right]^{\frac{\rho}{\rho-1}}, \nu \geq 0 .
$$

The parameter $\rho$ governs the elasticity of substitution between $C_{t}^{T}$ and $C_{t}^{N}$. The price of consumption services, $P_{t}$, is given by

$$
P_{t}=\left[\nu\left(P_{t}^{T}\right)^{1-\rho}+(1-\nu)\left(P_{t}^{N}\right)^{1-\rho}\right]^{\frac{1}{\rho-1}} .
$$

The variables $P_{t}^{T}$ and $P_{t}^{N}$ denote the local currency prices of tradables and nontradable goods, respectively.

Lifetime utility $(U)$ is given by:

$$
U=\sum_{t=0}^{\infty} \beta^{t}\left[u\left(C_{t}, N_{t}\right)+f\left(M_{t} / P_{t}\right)\right], \quad 0<\beta<1 .
$$

The variable $M_{t}$ represents beginning-of-period nominal money balances, and $f(\cdot)$ is a strictly concave function. As in Greenwood, Hercowitz, and Huffman (1988), we assume that $u(\cdot)$ takes the form

$$
u\left(C_{t}, N_{t}\right)=\frac{1}{1-\sigma}\left(C_{t}-B \frac{N_{t}^{1+\theta}}{1+\theta}\right)^{1-\sigma},
$$

where $B>0$. Given this specification of $u(\cdot)$, there are no wealth effects on labor supply, so the uncompensated labor-supply elasticity, $1 / \theta$, is equal to the Frisch elasticity. 
The household can borrow and lend in international capital markets at a constant dollar interest rate, $r$. For simplicity, we assume that inflation in the U.S. is equal to zero. To abstract from trends in the current account, we also assume that $\beta=1 /(1+r)$. The household's flow budget constraint is given by

$$
\begin{aligned}
& P_{t}^{T} C_{t}^{T}+P_{t}^{N} C_{t}^{N}+S_{t} a_{t+1}+M_{t+1}-M_{t}+T_{t}= \\
& W_{t} N_{t}+\Pi_{t}+(1+r) S_{t} a_{t} .
\end{aligned}
$$

The variable $a_{t}$ denotes the dollar value of household's net foreign assets. The variables $W_{t}$ and $T_{t}$ represent the nominal wage rate and nominal government transfers to the household, respectively. Total nominal profits in the economy are given by $\Pi_{t}$. The variable $S_{t}$ denotes the exchange rate expressed in units of local currency per dollar. We impose the no-Ponzi game condition

$$
\lim _{t \rightarrow \infty} \frac{a_{t+1}}{(1+r)^{t}}=0 .
$$

The Import Sector We assume that the tradable consumption good is imported. The dollar price of this good, $\bar{P}_{t}^{*}$, is set in international markets and is invariant to the level of domestic consumption. We assume that purchasing power parity (PPP) holds for prices "at the dock", i.e., the price of imports exclusive of distribution costs is

$$
\bar{P}_{t}^{T}=S_{t} \bar{P}_{t}^{*} .
$$

For convenience, we normalize $\bar{P}_{t}^{*}$ to one. The variable $\bar{P}_{t}^{T}$ denotes the domestic producer price of imports. In an earlier paper (Burstein, Eichenbaum, and Rebelo (2005)) argue that relative PPP is a reasonable approximation for the behavior of import prices at the dock after large devaluations.

As in Burstein, Neves, and Rebelo (2003) and Erceg and Levin (1996), we assume that selling a unit of a tradable consumption good requires $\phi$ units of the 
final nontradable good. Perfect competition in the distribution sector implies that the retail price of imported goods is equal to

$$
P_{t}^{T}=S_{t}+\phi P_{t}^{N} .
$$

The domestic distribution margin, which we define as the fraction of the final price accounted for by distribution costs, is equal to $\phi P_{t}^{N} / P_{t}^{T}$.

The Export Sector Exports are produced by a continuum of monopolistically competitive producers indexed by $i$. The size of this sector has measure one. Firm $i$ uses labor $\left(N_{i t}^{X}\right)$ to produce $X_{i t}$ units of exportable good $i$ using the technology

$$
X_{i t}=A^{X} N_{i t}^{X} .
$$

For simplicity, we assume that the representative household does not consume the export good. Demand for this good in the world market is given by

$$
X_{i t}=\xi\left(P_{i t}^{*}\right)^{-\gamma} .
$$

The variable $P_{i t}^{*}$ denotes the dollar retail price of export good $i$. The price elasticity of demand for the export good is given by $\gamma>1$.

As in Corsetti and Dedola (2004), we assume that to sell a unit of the exported good to foreign consumers, foreign retailers must add $\phi^{*}$ units of foreign distribution services. We normalize the dollar price of these services to one and assume that the distribution industry is competitive. It follows that $P_{i t}^{*}$ is given by

$$
P_{i t}^{*}=\bar{P}_{i t}^{X} / S_{t}+\phi^{*} .
$$

The variable $\bar{P}_{i t}^{X}$ denotes the producer price of the exported good. Under these assumptions, distribution costs affect the elasticity of demand for exports with respect to producer prices $\left(d \log \left(X_{i t}\right) / d \log \left(\bar{P}_{i t}^{X}\right)\right)$. The higher the distribution margin, the lower is the effective elasticity of demand. 
Producer $i$ maximizes profits, given by

$$
\Pi_{i t}^{X}=\left(\bar{P}_{i t}^{X}-W_{t} / A^{X}\right) X_{i t}
$$

The first-order conditions for this problem imply that all exporters charge the same price

$$
\bar{P}_{t}^{X} / S_{t}=\frac{\gamma\left(W_{t} / S_{t}\right) / A^{X}+\phi^{*}}{\gamma-1} .
$$

Total profits in the export sector are given by

$$
\Pi_{t}^{X}=\int_{0}^{1} \Pi_{i t}^{X} d i
$$

The Final Nontradable Good The final nontradable good $\left(Y_{t}^{N}\right)$ is produced by competitive firms using a continuum of differentiated inputs, $y_{i t}^{N}$, that are produced by the intermediate nontradable-goods sector. As in Kimball (1995), we assume that the production technology for $Y_{t}^{N}$ is given by the implicit function

$$
1=\int_{0}^{1} G\left(y_{i t}^{N} / Y_{t}^{N}\right) d i
$$

The function $G(\cdot)$ satisfies: $G(1)=1$ and $G^{\prime}(1)=1$. The standard Dixit-Stiglitz specification corresponds to the following specification for $G(\cdot)$,

$$
G\left(y_{i t}^{N} / Y_{t}^{N}\right)=\left(y_{i t}^{N} / Y_{t}^{N}\right)^{(\mu-1) / \mu} .
$$

The representative firm maximizes profits,

$$
\Pi_{t}^{N}=P_{t}^{N} Y_{t}^{N}-\int_{0}^{1} p_{i t} y_{i t}^{N} d i,
$$

subject to the production technology (2.11). The first-order condition for this problem is

$$
p_{i t}=\lambda G^{\prime}\left(y_{i t}^{N} / Y_{t}^{N}\right)\left(1 / Y_{t}^{N}\right) .
$$


Here, $\lambda$ is the Lagrange multiplier associated with equation (2.11).

Since the sector is competitive, equilibrium profits are zero and the price of the final nontradable good is

$$
P_{t}^{N}=\frac{\int_{0}^{1} p_{i t} y_{i t}^{N} d i}{Y_{t}^{N}} .
$$

In a symmetric equilibrium where all intermediate good firms charge the same price, $p_{i t}=p_{t}$, the price of the final nontradable good is

$$
P_{t}^{N}=p_{t} .
$$

The Intermediate Nontradable Good The nontradable intermediate good $i$ is produced by monopolist $i$ according to the technology

$$
y_{i t}^{N}=A^{N} N_{i t}^{N} .
$$

Monopolist $i$ chooses a price $p_{i t}$ to maximize profits given by:

$$
\Pi_{t}^{N}=p_{i t} y_{i t}^{N}-W_{t} y_{i t}^{N} / A^{N},
$$

and commits to satisfy demand at this price. The first-order condition for the monopolist's problem implies that

$$
p_{i t}=\left[\frac{\varepsilon\left(z_{i t}\right)}{\varepsilon\left(z_{i t}\right)-1}\right] \frac{W_{t}}{A^{N}} .
$$

Here, $z_{i t}=y_{i t}^{N} / Y_{t}^{N}$ denotes the market share of the $i$ th producer and $\varepsilon\left(z_{i t}\right)$ is the elasticity of demand for intermediate nontradable good $i$

$$
\varepsilon\left(z_{i t}\right)=-\frac{G^{\prime}\left(z_{i t}\right)}{z_{i t} G^{\prime \prime}\left(z_{i t}\right)} .
$$


We adopt the following functional form for $\varepsilon\left(z_{i t}\right):{ }^{2}$

$$
\varepsilon\left(z_{i t}\right)=\left\{\begin{array}{cc}
\varepsilon^{L}, & \text { if } z_{i t} \geq 1+\bar{z} \\
\varepsilon^{H}, & \text { if } z_{i t} \leq 1-\bar{z} \\
\frac{1}{2 \bar{z}}\left[\left(1+\bar{z}-z_{i t}\right) \varepsilon^{H}+\left(z_{i t}-1+\bar{z}\right) \varepsilon^{L}\right], & \text { if } 1-\bar{z} \leq z_{i t} \leq 1+\bar{z}
\end{array}\right.
$$

This specification implies that in a symmetric equilibrium $\left(z_{i t}=1\right)$, the elasticity common to all the monopolists is

$$
\varepsilon(1)=\frac{\varepsilon^{H}+\varepsilon^{L}}{2}
$$

The optimal mark-up is

$$
\mu=\frac{\varepsilon(1)}{\varepsilon(1)-1} .
$$

Once $\bar{z}$ is specified, the parameters $\varepsilon^{L}$ and $\varepsilon^{H}$ jointly determine the average markup and the local slope of the mark-up around the point $z_{i t}=1$. Given a value for $\varepsilon^{H}$, we choose $\varepsilon^{L}$ so that $\mu$ is equal to the calibrated steady-state mark-up. With these assumptions, the symmetric equilibrium is the same as the one in which $G(\cdot)$ takes the Dixit-Stiglitz form, (2.12), so

$$
p_{i t}=p_{t}=\mu \frac{W_{t}}{A^{N}} .
$$

In practice, we set $\bar{z}$ to a very small number $(0.0001)$ so that $\varepsilon\left(z_{i t}\right)$ is close to a step function. Therefore, a firm that deviates from a symmetric equilibrium by raising its price faces a discrete increase in the elasticity of demand for its product. In the standard Dixit-Stiglitz case $\varepsilon\left(z_{i t}\right)=\mu$ and $p_{i t}$ is a constant mark-up over marginal cost. Relative to the Dixit-Stiglitz case, firms in our model have less of an incentive to raise prices.

\footnotetext{
${ }^{2}$ We thank Miles Kimball for suggesting this functional form.
} 
Government The government chooses a money supply sequence, $\left\{M_{t}^{s}\right\}_{t=1}^{\infty}$, and rebates any seignorage revenue to the household via lump-sum transfers:

$$
M_{t+1}^{s}-M_{t}^{s}=T_{t}
$$

Equilibrium and Definition of the RER A perfect-foresight, competitive equilibrium for this economy is a set of paths for quantities $\left\{X_{i t}, N_{i t}^{X}, y_{i t}^{N}, Y_{t}^{N}\right.$, $\left.N_{i t}^{N}, C_{t}, C_{t}^{N}, C_{t}^{T}, N_{t}, a_{t+1}, M_{t+1}\right\}$ and prices $\left\{P_{i t}^{*}, \bar{P}_{i t}^{X}, W_{t}, S_{t}, p_{i t}, P_{t}^{N}, \bar{P}_{t}^{T}, P_{t}^{T}\right\}$ such that households maximize their utility and firms maximize profits; the government's budget constraint holds; and the goods, labor, money, and foreign exchange markets clear. We restrict our attention to symmetric equilibria in which all nontradable-goods producers choose the same price and quantity.

We define the RER as:

$$
R E R=\frac{P_{t}}{S_{t} P_{t}^{*}}
$$

Here, $P_{t}^{*}$ denotes the foreign CPI. In our empirical measures of the RER, we compute both $S_{t}$ and $P_{t}^{*}$ as trade-weighted averages of exchange rates and foreign CPIs. With the exception of Uruguay, movements in $P_{t}^{*}$ are quite small relative to the size of the devaluation. So, to simplify, we normalize $P_{t}^{*}$ to one in the model.

\section{Basic Results}

Here we study the quantitative properties of our model. We consider three numerical examples motivated by different devaluation episodes: Korea (1997), Uruguay (2002), and the UK (1992). Korea and Uruguay experienced large devaluations that were followed by contractions in aggregate economic activity.

In Korea, inflation remained stable after the devaluation. In contrast, in Uruguay, inflation rose substantially after the devaluation. The UK devaluation was relatively small and was followed by a mild expansion and stable inflation. 
In the Korean example, we generate a recession by assuming that net foreign assets, $a_{0}$, decline at the time of the devaluation. We calibrate the change in $a_{0}$ so that our benchmark model generates a fall in real consumption consistent with that observed in Korea in the first year after the devaluation. We assume that the decline in $a_{0}$ coincides with a 37 percent unanticipated, permanent devaluation. This devaluation coincides with the change in the trade-weighted exchange rate for the won in the first year after the devaluation. For expositional purposes we also consider the impact of a devaluation in the Korean example when there is no coincident decline in real wealth.

The Uruguayan devaluation coincided with a large decline in the demand for their exports, which stemmed from the 2001 Argentina currency crisis. Drawing on this observation, we assume in our Uruguayan example that the devaluation coincides with a fall in $\xi$, the level parameter in the export demand equation (2.8). We choose the devaluation rate in our example, 42 percent, to coincide with the cumulative devaluation in the trade-weighted peso exchange rate from January 2002 to June 2003. We note that the Uruguayan devaluation occurred in June 2002, but the trade-weighted nominal exchange rate changed substantially before June 2002 due to the Argentina January 2002 devaluation. For this reason we choose January 2002 as our reference point.

For our UK example, we abstract from real shocks and consider a pure devaluation of 11 percent. This devaluation coincides with the trade-weighted change in the exchange rate for the pound sterling in the first year after the UK devaluation.

In all of the examples, we assume that prior to time zero agents anticipate that the exchange rate is fixed at $S_{t}=S$ and that the economy is in a steady state with constant prices and quantities. At time zero, there is an unanticipated change in monetary policy that leads to a one-time permanent exchange-rate devaluation. Depending on the example, there can be a real shock that coincides with the 
devaluation.

We summarize the parameter values for our benchmark model in Table 1. Our results are independent of the function $f($.$) , which controls the utility of$ real balances (see equation (2.3)). We set the elasticity of substitution between tradables and nontradables $(\rho)$ to 0.40 . This value is consistent with estimates in the literature. ${ }^{3}$ For each country, we set $\nu$, the share parameter in the CES consumption aggregator in equation (2.1), so that given $\phi$, the pre-devaluation share of import goods in consumption, exclusive of distribution costs, coincides with the data reported in Burstein, Eichenbaum, and Rebelo (2005). We assume that $\theta=0.25$. This value implies a labor supply elasticity of four which coincides with the standard value of the Frisch labor supply elasticity used in the realbusiness-cycle literature (see Christiano and Eichenbaum (1992) and King and Rebelo (2000)). We choose $B$, the level parameter that controls the disutility of labor, so that the price of nontradables in the pre-devaluation steady state is equal to one.

We set $\phi$ and $\phi^{*}$ so that the pre-devaluation distribution margin is 50 percent in both the domestic and foreign markets. This value is consistent with the evidence in Burstein, Neves, and Rebelo (2003).

We set the level parameter in the demand for exports, $\xi$, to one. The elasticity of demand for exports, $\gamma$, controls how much the export sector expands in the wake of the devaluation. For every country, we set $\gamma$ so that the model replicates the expansion in exports that occurs in the year after the devaluation (see Table 1).

We require a relatively inelastic demand so that the model yields a plausible post-devaluation expansion of the export sector. This low elasticity is a simple

\footnotetext{
${ }^{3}$ See, for example, Stockman and Tesar (1995); Lorenzo, Aboal, and Osimani (2003); and Gonzalez-Rozada and Neumeyer (2003).
} 
way to mimic the frictions that limit in practice the expansion of the export sector, e.g. capacity constraints, financing constraints, or frictions to sectoral employment reallocation.

For every country, we set the level parameter in the production function of the export sector, $A^{X}$, and the initial level of net foreign assets $\left(a_{0}\right)$ so that the share of exports in GDP in the model's steady state is equal to its value in the year prior to the devaluation.

We choose the intermediate demand aggregator parameters, $\varepsilon^{L}$ and $\varepsilon^{H}$, so that the model has two properties. First, the steady-state mark-up is 20 percent. Second, the parameters are consistent with the calibration used by Kimball (1995) to generate sticky prices in a closed economy. This calibration has the property that when the relative market share $\left(z_{i t}\right)$ decreases, the elasticity of demand increases from six to nine. Given how little information is available to calibrate the Kimball aggregator, we report the sensitivity of our results to alternative calibrations. We consider a calibration such that it is optimal for the deviator to change his price by 50 percent of the increase in marginal cost. This calibration is consistent with the symmetric translog specification of Bergin and Feenstra (2000). These two specifications of the demand aggregator encompass the calibration used by Dotsey and King (2005), which lies in between the Kimball and Bergin-Feenstra specifications. Finally, we also consider the standard Dixit-Stiglitz specification of demand in which the elasticity of demand is constant.

The Korean Example The first two columns of Table 2 report the response of the benchmark model to a single shock: a 37 percent devaluation. Columns 1 and 2 correspond to the case of flexible and sticky nontradable-goods prices, respectively, when there is no real shock. Columns 3 and 4 report the impact of two simultaneous shocks: a 37 percent devaluation and a negative wealth shock 
for the flexible and sticky price case, respectively. ${ }^{4}$ We start with the case in which there is no real shock to build intuition that is useful for understanding the empirically relevant case of when there is a negative real shock.

\section{No Real Shock}

Column 1 of Table 2 indicates that when prices are flexible, the devaluation has no impact on quantities, whereas all prices, including the nominal wage, increase by 37 percent.

Column 2 of Table 2 shows that when nontradable-goods prices are sticky, the devaluation induces a low rate of CPI inflation (8.7 percent). Even though PPP holds for import prices at the dock, the presence of distribution costs implies that the retail price of imported goods rises by only 20.4 percent.

When nontradable-goods prices are sticky, the devaluation leads to a rise in hours worked (9.9 percent). To understand the expansion in hours worked we briefly discuss the response of output in the export and nontradable sectors.

The devaluation induces a fall in the dollar wage rate $(W / S)$, which reduces the marginal cost of producing export goods. This reduction leads to a 8.4 percent decline in the dollar price of exports $\left(\bar{P}^{X} / S\right)$ and a 10.4 percent rise in the volume of exports (see Table 2). To understand the behavior of $\bar{P}^{X} / S$ and $W / S$, we note that the optimal response of export goods producers to a decline in marginal cost is to lower their dollar price and sell more units. Consistent with equation (2.10), absent foreign distribution costs $\left(\phi^{*}=0\right)$, the percentage declines in $\bar{P}^{X} / S$ and $W / S$ would be the same. However, as emphasized by Corsetti and Dedola (2004), when $\phi^{*}>0$, a one percent decline in the dollar price of exports $\left(\bar{P}^{X} / S\right)$ induces a less than one percent decline in the retail dollar price of exports. Consequently,

\footnotetext{
${ }^{4}$ We also analyze the Korean example by assuming that the real shock is a decline in the demand for exports. Our results are similar those obtained with the net foreign asset shock. The only difference is that exports rise by less when there is a negative shock to export demand.
} 
the price reduction induces a smaller rise in the demand for the product. Put differently, a positive value of $\phi^{*}$ reduces the effective elasticity of demand with respect to $\bar{P}^{X} / S$. Therefore, the optimal response of the monopolist is to lower $\bar{P}^{X} / S$ by less than when $\phi^{*}=0$.

According to Table 2 consumption of tradable goods rises by 3.7 percent. To understand this effect note that in equilibrium the following condition must hold:

$$
r a_{t}=r a_{0}=C_{t}^{T}-\left(\bar{P}_{t}^{X} / S_{t}\right) X_{t}
$$

To derive this equation we start with (2.5) and rewrite profits as sales revenue minus labor costs. We then use equations $(2.17)$, (2.6), the market clearing condition for nontradable goods, and the intertemporal Euler equation for tradable consumption. The assumptions that $\beta=1 /(1+r)$ and shocks are permanent imply that $a_{t}$ is constant $\left(a_{t}=a_{0}\right)$. It follows from (3.1) that imports $\left(C_{t}^{T}\right)$ must rise to match export revenues.

To explain the response of hours worked in the nontradable-goods sector we note that the consumer's first-order conditions for $C_{t}^{T}$ and $C_{t}^{N}$ imply that

$$
\frac{C_{t}^{N}}{C_{t}^{T}}=\left[\frac{P_{t}^{T}}{P_{t}^{N}}\right]^{\rho} .
$$

We note that $P_{t}^{T} / P_{t}^{N}$ rises, since $P_{t}^{N}$ remains constant and $P_{t}^{T}$ rises in response to the devaluation (see equation (2.7)). Since both $C_{t}^{T}$ and the right-hand side of equation (3.2) rise, it follows that $C_{t}^{N}$ must also rise. By assumption, nontradablegoods firms must satisfy demand at fixed prices, so hours worked in the nontradable sector rise. Since hours worked in both the export and nontradable-goods sectors increase so do the overall hours worked.

The wage rate that is relevant for labor supply decisions is the CPI-deflated real wage, $W_{t} / P_{t}$. Given our assumptions about preferences $W_{t} / P_{t}$ must rise, because 
hours worked $\left(N_{t}\right)$ increase. Since $N_{t}$ rises by 9.9 percent and the elasticity of labor supply is four, $W_{t} / P_{t}$ must rise by roughly $9.9 / 4$ percent. ${ }^{5}$ The dollar-denominated wage falls by 26.4 percent, but this wage is not relevant for labor-supply decisions. Most of the worker's consumption basket is composed of nontradable goods whose prices have not changed. As a result, CPI and dollar-deflated real wages respond very differently to the devaluation.

The real-wage rate is constant in the flexible-price case and rises when prices are sticky. The increase in the nominal wage, $W_{t}$, is smaller in the sticky-price case because CPI inflation is much lower than in the flexible-price case.

Table 2 reports that the mark-up of nontradable-goods producers falls to 7.6 percent after the devaluation. A key question is, how great is the incentive of an individual nontradable-goods firm to deviate from the symmetric sticky price equilibrium? According to Table 2, the optimal mark-up for the deviator is 12.5 percent and the percentage increase in his profits is 9.9 percent. Consequently, the loss from keeping prices constant for a long period of time would be very great. We conclude that absent any real shocks, a large devaluation would lead firms to change prices and the economy would go to the flexible-price equilibrium.

\section{Negative Real Shock}

Column 3 of Table 2 shows that when prices are flexible, a devaluation of 37 percent leads to a 23.1 percent rise in the CPI. A devaluation also induces a fall in the dollar price of exports, an expansion of hours worked in the export sector, and an even greater drop in hours worked in the nontradable-goods sector. In addition, there is a decline in the dollar price of nontradable goods and in the dollar and CPI-deflated real wages.

\footnotetext{
${ }^{5}$ The nominal wage rate reported in Table 2 rises by somewhat less than $9.9 / 4$ because we compute the CPI reported in our tables as an arithmetic average of tradable and nontradable prices. The rate of change in the arithmetically averaged CPI is similar to the rate of change the theoretical price index that corresponds to the household's utility function (see equation (2.2)).
} 
These effects happen because when there is a negative real shock, the devaluation coincides with a decline in net foreign assets. According to equation (3.1) a decline in $a_{t}$ must be accompanied by either an improvement in the trade balance $\left(C_{t}^{T}-\left(\bar{P}_{t}^{X} / S_{t}\right) X_{t}\right)$. In principle, this reduction can be accomplished by increasing exports or reducing imports. Exports can be increased either by raising aggregate hours worked or by reallocating workers from the nontradable-goods sector to the export sector.

Given our preference specification, it is not optimal to respond to a decline in $a_{0}$ solely through a fall in $C_{t}^{T}$, so that $X_{t}$ must rise. For exports to rise, the dollar price of exports must fall. Equation (2.10) implies that the dollar wage must also fall. Under flexible prices (but not under sticky prices) whenever the dollar wage declines the CPI-deflated real wage also declines. To see this we note that the CPI-deflated real wage is

$$
W_{t} / P_{t}=W_{t} /\left[\nu\left(P_{t}^{T}\right)^{1-\rho}+(1-\nu)\left(P_{t}^{N}\right)^{1-\rho}\right]^{\frac{1}{\rho-1}} .
$$

Using equations (2.14), (2.16), and (2.7) this expression can be rewritten as

$$
W_{t} / P_{t}=1 /\left[\nu\left(S_{t} / W_{t}+\phi \mu / A^{N}\right)^{1-\rho}+(1-\nu)\left(\mu / A^{N}\right)^{1-\rho}\right]^{\frac{1}{\rho-1}} .
$$

Our preference specification implies that aggregate hours worked depend only on the wage rate. Therefore aggregate hours worked fall. It follows that there must be a substantial decline in nontradable consumption to allow for a rise in the production of exports.

Since nontradable-goods prices are a mark-up on wages, the drop in dollar wages leads to a decline in the dollar price of nontradable goods. This decline creates a wedge between the devaluation rate (37 percent) and the CPI inflation rate (23 percent). However, even though the CPI inflation is lower than the change in the exchange rate, it is much higher that the actual rate of inflation in Korea (6.6 percent). 
Column 4 of Table 2 shows that when nontradable-goods prices are sticky, the CPI inflation in the model (8.7 percent) is much closer to the actual rate of inflation (6.6 percent). Thus, the model does well in accounting for the postdevaluation decline in the RER.

Viewed as a whole, our results indicate that when nontradable-goods prices are sticky, the model successfully accounts for low post-devaluation rates of inflation. This result begs the question, is it reasonable to assume that nontradable-goods prices are sticky? To answer this question, we calculate the incentive of an individual nontradable-goods monopolist to deviate from a symmetric sticky-price equilibrium. The percentage change in profits of a deviator is equal to zero (see column 4 of Table 2). If there are any costs of changing prices, nontradable-goods producers will keep their prices constant, thus rationalizing the sticky-price equilibrium. ${ }^{6}$ The gains to deviating from a sticky-price equilibrium are very small, when there is a negative real shock but large otherwise. This difference reflects the fact that nominal wages rise by much less when there is a negative real shock.

The Uruguay Example Table 3 reports the results of a 42 percent devaluation that coincides with a fall in $\xi$, the level parameter in the demand for exports (2.8), from one to 0.69. When nontradable-goods prices are flexible, the CPI inflation in the model (26 percent) is close to the actual rate of inflation (29 percent). This result suggests that sticky prices did not play a significant role in the Uruguayan case. Even though the model does well in accounting for the post-devaluation rate of inflation, it understates the post-devaluation decline in the RER (15.5 compared to 30.6). This shortcoming is due to the fact that the model abstracts from changes in the international price of tradable goods, $P_{t}^{*}$. In the year after

\footnotetext{
${ }^{6}$ There is, of course, another equilibrium in which all nontradable goods producers change their prices. The existence of two equilibria, one in which prices are sticky and one in which all firms change prices, is a generic property of models that emphasize costs of changing prices.
} 
the Uruguayan devaluation there was a large rise in the CPI of Uruguay's major trading partners. This rise was associated primarily with a high rate of inflation in Uruguay's main trading partner, Argentina.

The CPI inflation is lower that the rate of devaluation because, other things equal, a negative shock to export demand induces a decline in export revenues. Given agents' preferences, it is not optimal to match this decline with only a fall in $C_{t}^{T}$, therefore $\bar{P}_{t}^{X} / S_{t}$ must fall to mitigate the decline in $X_{t}$. It follows from (2.10) that the dollar wage must fall, so that nominal wages must rise by less than the rate of devaluation. Since nontradable-goods prices are a mark-up on nominal wages they also rise by less than the rate of devaluation. This result in turn implies that the rate of CPI inflation is lower than the rate of devaluation.

The previous results suggest that the flexible-price version of the model can account for post-devaluation inflation rates in Uruguay. This conclusion leads us to ask whether or not the sticky price equilibrium was sustainable in Uruguay. To answer this question, we compute the equilibrium of the model under the assumption that nontradable-goods prices are sticky. We then assess the gains to a nontradable firm from deviating from that equilibrium. According to column 2 of Table 3, the gains are equal to roughly one percent of a deviator's profits. These calculations indicate that a sticky-price equilibrium would not have been sustainable in Uruguay.

The UK Example Column 1 of Table 4 reports the response of our model economy to a permanent 11 percent devaluation when prices are flexible. In this case, there is no impact on real quantities, and prices increase by the rate of devaluation. This version of the model clearly cannot account for the low postdevaluation rate of inflation and mild expansion observed in the UK.

Column 2 of Table 4 reports results for the sticky-price case. The intuition 
behind these results is similar to that underlying the Korean case when there is no real shock. The key result here is that the CPI inflation is only 2.4 percent, which is roughly consistent with the CPI inflation in the data (1.7 percent). Also, consistent with the data, the model generates a mild expansion after the devaluation. We infer that the sticky nontradable-goods price model captures the salient features of the UK devaluation episode. As above, the key question is whether sticky prices are sustainable as an equilibrium phenomenon. Table 4 indicates that the answer to this question is yes. The gain to a nontradable-goods producer of deviating from a symmetric sticky price equilibrium is equal to zero under the Kimball (1995) specification of the nontradable-goods demand aggregator..

\section{Isolating the Key Margins}

Here, we use the UK example to discuss the mechanisms that enable our model to account for sticky nontradable-goods prices. We conduct this analysis by abstracting from real shocks, because the intuition is easier to convey when the only shock is a change in the exchange rate.

As noted, the optimal price for a nontradable-goods producer who chooses to deviate from a symmetric sticky nontradable-goods price equilibrium is given by

$$
p_{i t}=\mu \frac{W_{t}}{A^{N}} .
$$

The only way in which different specifications of the demand for nontradable goods affect $p_{i t}$ is through their impact on the gross mark-up, $\mu$. Other features of the model influence $p_{i t}$ because they affect the response of nominal wages to shocks.

To discuss the sensitivity of our results to our benchmark specification of the nontradable-goods demand aggregator, we consider two alternatives. First, we choose the parameters of the nontradable-goods demand aggregator (2.15) 
to be consistent with the specification proposed by Bergin and Feenstra (2000). Second, we consider the standard Dixit-Stiglitz demand specification. In both cases, we calibrate the demand aggregators so that the pre-devaluation values of all quantities and prices are the same as in our benchmark specification. Thus, different specifications of the aggregator only affect the benefit to a nontradablegoods producer of deviating from a symmetric sticky-price equilibrium.

Column 2 of Table 4 summarizes the benefit to a deviator for different specifications of the demand aggregator. As we have noted, the benefit is roughly zero for the Kimball case. With the Bergin-Feenstra calibration, the benefit is roughly 0.5 percent of profits. The present value of this gain is still moderate relative to the costs of changing prices estimated by Levy, Bergen, Dutta, and Venable (1997) and Zbaracki, Ritson, Levy, Dutta, and Bergen (2004). With the Dixit-Stiglitz specification, the benefit to a deviator rises to 1.7 percent of profits. We conclude that our results are reasonably robust to modifications of the demand aggregator, as long as we do not go to the extreme of the Dixit-Stiglitz specification.

We also wish to explore the impact of other key parameters on the response of the nominal wage to the devaluation and on firm's incentives to deviate from the sticky price equilibrium. For every change in a model parameter, we recalibrate the value of $a_{0}$ so that the pre-devaluation share of exports in GDP remains constant. We use this procedure to facilitate comparisons across the different specifications. For a small devaluation, such as that of the UK, the benefits from deviating from the sticky-price equilibrium for the Kimball specification are always close to zero. Therefore we focus our sensitivity analysis on the Bergin-Feenstra specification.

First, we consider the impact of foreign distribution costs. Column 2 of Table 5 reports results for the case in which the foreign distribution margin is zero instead of 50 percent. In this case, there is a smaller rise in the local currency price of exports (5.7 percent compared to 8.1 percent) and a larger fall in $\bar{P}^{X} / S(-5.6$ 
percent compared to -3.2 percent). As noted, a fall in $\phi^{*}$ raises the effective demand elasticity faced by export-goods producers. This fall makes it optimal for producers to lower $\bar{P}^{X} / S$ by more than they do when $\phi^{*}$ is positive. Relative to the benchmark case, the associated increase in demand leads to a larger expansion in hours worked in the export sector and a greater rise in the nominal wage (5.7 percent compared to 3.1 percent). Consequently, the percentage increase in profits from deviating from the symmetric sticky-goods price equilibrium rises from 0.5 percent to 3.7 percent. We infer that the presence of foreign distribution costs helps rationalize the sticky-price equilibrium.

Column 3 reports the impact of changing the parameter $\nu$ so that the share of traded goods (inclusive of distribution) in the CPI bundle falls from 40 percent to 25 percent. The devaluation now leads to a lower rate of CPI inflation (1.5 percent compared to 2.4 percent) and to smaller rise in nominal wages (2.6 percent compared to 3.1 percent). The benefit to the deviator falls from 0.5 to 0.2 percent of profits. We conclude that a small share of traded goods in the CPI bundle plays a positive role in rationalizing sticky nontradable-goods prices.

Column 4 reports the results we obtain by increasing the elasticity of substitution between tradables and nontradables from 0.4 to one. This change implies that the demand for nontradable goods is more responsive to a change in the price of imported consumption goods relative to nontradable-goods. Relative to the benchmark specification, the devaluation induces larger rises in the demand for nontradable-goods, hours worked in the nontradable-goods sector, and nominal wages. ${ }^{7}$ The percentage change in profits for a deviator rises from 0.5 percent to 0.9 percent of profits. We conclude that a low degree of substitution between nontradable goods and imported goods helps rationalize sticky nontradable-goods

\footnotetext{
${ }^{7}$ An offsetting effect results from the fact that the theoretical consumption deflator changes by less since the two goods are more substitutable. Other things equal, this effect leads to a smaller increase in the nominal wage.
} 
prices.

Column 5 reports the results we obtain by eliminating domestic distribution costs. Setting $\phi$ equal to zero increases the effective share of pure tradable goods in consumption and the effective elasticity of substitution between tradables and nontradables. For the reasons discussed above, both these effects imply that, after the devaluation, nominal wages rise by more than they do in the benchmark model. The incentive for nontradable goods firms to change their price is 3.9 percent compared to 0.5 percent of profits in the benchmark model. We conclude that sticky nontradable goods prices are easier to rationalize in the presence of domestic distribution costs.

Column 6 reports results of increasing the elasticity of demand for exports, $\gamma$, from 2.7 to 3.7 . This change in $\gamma$ increases the response of exports for two reasons. First, for a given drop in $\bar{P}^{X} / S$, there is a larger increase in exports. Second, the equilibrium fall in $\bar{P}^{X} / S$ is actually larger. Raising $\gamma$ has the same effect as lowering $\phi^{*}$ on the elasticity of $\bar{P}^{X} / S$ with respect to $W / S$. For the reasons discussed above, $\bar{P}^{X} / S$ becomes more responsive to the drop in $W / S$. Therefore, the decline in $\bar{P}^{X} / S$ is greater than in the benchmark model, which leads to a larger expansion in the export sector. There is also a larger increase in the nominal wage. The benefit of changing the price of nontradable goods increases from 0.5 to 1.2 percent of profits. A low elasticity of demand for exports helps to rationalize sticky prices in our model.

Column 7 summarizes the impact of lowering the share of exports in GDP from 23 percent to 10 percent. This value is closer to the pre-devaluation export shares in Argentina (10.9 percent) and Brazil (10.6 percent). In our model, a smaller export sector reduces the absolute value of the post-devaluation rise in hours worked in the export sector. ${ }^{8}$ Consequently, there is a smaller rise in nominal

\footnotetext{
${ }^{8}$ This is consistent with evidence in Gupta, Mishra and Sahay (2001) that suggests that the
} 
wages. The percentage change in profits for a deviator falls from 0.5 percent to 0.4 percent of profits. We conclude that a smaller share of exports in GDP helps rationalize the sticky-price equilibrium.

Column 8 reports the impact of lowering the labor supply elasticity from four to one. Relative to the benchmark model, there is a greater rise in the nominal wage and the CPI-deflated real wage. The greater impact on wages is a direct consequence of the lower labor-supply elasticity. These gains from deviating from the symmetric sticky nontradable-goods price equilibrium rise from 0.5 percent to 2.7 percent of profits. A high elasticity of labor supply is clearly critical in accounting for sticky prices.

\section{An Overvaluation Experiment}

A standard way of formalizing the notion that an exchange rate is overvalued is to assume that traded goods prices are sticky in domestic currency. Here, we discuss an alternative, complementary mechanism through which exchange rates can become overvalued. We show that if nontradable-goods prices do not change after a real shock, the exchange rate becomes overvalued. By this we mean that the real exchange rate is higher than it would be under flexible prices.

We consider an economy that is in the steady state of a fixed exchange rate regime. For convenience, we normalize the foreign price level to one and define the real exchange rate as $R E R=P_{t} / S_{t}$. For expositional purposes we consider the Korean example, where the economy suffers a decline in its net foreign assets, $a_{t}$. Qualitatively similar results obtain if there is a negative shock to export demand, as in our Uruguay example.

Table 6 reports the response of the economy to a decline in net foreign assets, the negative real shock considered in Table 2, under different scenarios. The expansionary effect of a devaluation is stronger when the tradable sector is larger. 
numbers we report are rates of change relative to the pre-shock steady state.

Column 1 reports results for the case of flexible prices with no devaluation. Equation (3.1) implies that a decline in net foreign assets requires an improvement in the trade balance. Given our assumptions about preferences, this improvement occurs via both a decline in imports and an increase in exports. The decline in imports is achieved through an increase in the retail price of imports relative to nontradables, $P_{t}^{T} / P_{t}^{N}=S_{t} / P_{t}^{N}+\phi$ (see equation (3.2)). Since $S_{t}$ is fixed, a rise in $P_{t}^{T} / P_{t}^{N}$ requires a drop in $P_{t}^{N}$, which in turn induces a decline in the $P_{t}$ (see equations (2.7) and (2.2)) and in the RER.

What are the consequences for wages and hours worked? Since the price of nontradables falls, the nominal wage, $W_{t}$, also falls (see equation (2.16)). The response of aggregate hours depends on the behavior of the CPI-deflated real wage, $W_{t} / P_{t}$. To see what happens to $W_{t} / P_{t}$ we recall that to achieve an improvement in the trade balance, the quantity of exports must rise. This rise requires a fall in the dollar price of exports, $\bar{P}_{t}^{X} / S_{t}$. The drop in $\bar{P}_{t}^{X} / S_{t}$ induces a decline in both the dollar-denominated wage, $W_{t} / S_{t}$ and $W_{t} / P_{t}$ (see equations (2.10), (3.3), and (3.4)). The drop in $W_{t} / P_{t}$ leads to a decrease in aggregate hours worked.

Column 2 reports the response of the economy to the negative real shock when nontradable-goods prices are sticky and there is no devaluation. The rate of the CPI inflation is zero and the RER remains constant. When we compare columns one and two we see that the $R E R$ is 14.2 percent higher when nontradable-goods prices are sticky. In this sense, sticky nontradable-goods prices lead to an overvalued exchange rate after a negative real shock.

In the sticky-price equilibrium, the nominal wage falls by less than it does when nontradable-goods prices are flexible. This smaller wage decline implies that the dollar price of exports falls by less than when prices are flexible $(-1.7$ percent compared to -5.9 percent). As a result, there is a smaller expansion in 
exports when nontradadable-goods prices are sticky (2.2 percent compared to 7.3 percent). Equation (3.1) implies that consumption of imported goods must fall by more in the sticky-price equilibrium.

To explain the response of hours worked in the nontradable-goods sector we note that with a fixed exchange rate and sticky nontradable prices, the right-hand side of (3.2) is fixed. Consequently, the percentage declines in $C_{t}^{N}$ and $C_{t}^{T}$ are the same (23.6 percent). In contrast, under flexible prices, the negative real shock leads to a decline in $P_{t}^{N} / P_{t}^{T}$ and a rise in $C_{t}^{N} / C_{t}^{T}$. This rise, together with the fact that $C_{t}^{T}$ drops by less under flexible prices, implies that $C_{t}^{N}$ also falls by less under flexible prices. Since the hours worked in the export sector rise by more in the flexible-price case, the previous argument establishes that the recession induced by the real shock is mitigated by flexible prices.

Given that nontradable-goods prices remain constant and the wage falls, the mark-up of nontradable-goods producers rises (from 20 percent to 26.3 percent). An individual producer could raise his profit by lowering his price relative to the symmetric sticky-price equilibrium. As Table 6 shows, the resulting rise in profits is zero if we assume a Kimball demand aggregator. This rise in profits is very modest (0.7 percent of profits) for the Bergin-Feenstra aggregator.

The previous results show that if nontradable-goods prices are sticky, then the impact of a real shock to the economy leads to a smaller decline in the real exchange rate and a larger contraction than would be the case under flexible prices. In this sense, the negative real shock results in the exchange rate being overvalued. Under these circumstances, a devaluation leads to an expansion in economic activity and helps realign the real exchange rate.

Our model is consistent with the conventional wisdom that prices do not increase after a large devaluation, because they were too high before the devaluation. If we suppose that the exchange is overvalued in the sense just described above, 
then a devaluation that preserves the sticky nontradable-goods price equilibrium leads to a decline in the real exchange rate without a substantial amount of inflation (see column 3 of Table 6).

\section{Conclusion}

We propose an open economy, general equilibrium model that can account for the substantial drop in real exchange rates that occurs in the aftermath of large devaluations. Our model embodies several elements that dampen wage pressures in the wake of a devaluation. If the nominal wage remains relatively stable in the aftermath of a large devaluation, this stability can eliminate the incentive for nontradable-goods producers to change their prices. If nontradable-goods prices remain stable, inflation is low, which is compatible with a stable nominal wage rate.

We conclude by noting an important shortcoming of our paper. To simplify our analysis, we focus on rationalizing a post-devaluation equilibrium in which nontradable-goods prices do not change at all. In reality, these prices do change, albeit by far less than the exchange rate, the price of imports and exportables, or the retail price of tradable goods. Modeling the detailed dynamics of nontradablegoods prices is a task that we leave for future research. 


\section{References}

[1] Aghion, Philippe, Philippe Bachetta and Abhijit Banerjee, "Currency Crisis and Monetary Policy in an Economy with Credit Constraints," European Economic Review, 45: 1121-1150, 2001.

[2] Ball, Laurence and David Romer, "Real Rigidities and the Non-Neutrality of Money," Review of Economic Studies, 57: 183-203, 1990.

[3] Bergin, Paul and Robert Feenstra, "Staggered Price Setting, Translog Preferences, and Endogenous Persistence," Journal of Monetary Economics, 45: 657-680, 2000.

[4] Burnside, Craig, Martin Eichenbaum and Sergio Rebelo, "Hedging and Financial Fragility in Fixed Exchange Rate Regimes," European Economic Review, 45: 1151-1193, 2001.

[5] Burstein, Ariel, Martin Eichenbaum and Sergio Rebelo, "Large Devaluations and the Real Exchange Rate," Journal of Political Economy, 113: 4, 742-784, August 2005.

[6] Burstein, Ariel, Joao Neves, and Sergio Rebelo, "Distribution Costs and Real Exchange-Rate Dynamics During Exchange-Rate-Based Stabilizations," Journal of Monetary Economics, 50: 1189-1214, 2003.

[7] Caballero, Ricardo and Arvind Krishnamurthy, "International and Domestic Collateral Constraints in a Model of Emerging Market Crises," Journal of Monetary Economics 48: 513-548, 2001.

[8] Christiano, L. and M. Eichenbaum, "Current Real Business Cycle Theories and Aggregate Labor Market Fluctuations," American Economic Review, 82: 430-50, 1992. 
[9] Christiano, Lawrence, Christopher Gust, and Jorge Roldos, "Monetary Policy in a Financial Crisis," Journal of Economic Theory, 119: 64-103, 2004.

[10] Corsetti, Giancarlo and Luca Dedola, "Macroeconomics of International Price Discrimination," forthcoming Journal of International Economics, 2004.

[11] Dotsey, Michael and Robert G. King, "Implications of State-dependent Pricing for Dynamic Macroeconomic Models," Journal of Monetary Economics, 52: 213-242, 2005.

[12] Erceg, Christopher and Andrew Levin, "Structures and the Dynamic Behavior of the Real Exchange Rate," mimeo, Board of Governors of the Federal Reserve System, 1996.

[13] Gonzalez-Rozada, Martín and Pablo Andrés Neumeyer "The Elasticity of Substitution in Demand for Non-tradable Goods in Latin America Case Study: Argentina," mimeo, Universidad T. Di Tella, 2003.

[14] Gordon, Robert, "The Aftermath of the 1992 ERM Breakup: Was There a Macroeconomic Free Lunch?" in Paul Krugman (ed.) Currency Crises, University of Chicago Press, 241-82, 2000.

[15] Greenwood, Jeremy, Zvi Hercowitz and Gregory Huffman, "Investment, Capacity Utilization, and the Real Business Cycle," American Economic Review 78: 402-417, 1988.

[16] Gupta, Poonam, Deepak Mishra and Ratna Sahay, "Output Response to Currency Crises," mimeo, International Monetary Fund, 2001.

[17] Kimball, Miles S., "The Quantitative Analytics of the Basic Neomonetarist Model," Journal of Money, Credit and Banking, 27: 1241-1277, 1995. 
[18] King, Robert and Sergio Rebelo, "Resuscitating Real Business Cycles", in John Taylor and Michael Woodford (eds.) Handbook of Macroeconomics, North-Holland, 927-1007, 2000.

[19] Levy, Daniel, Mark Bergen, Shantanu Dutta, and Robert Venable, "The Magnitude of Menu Costs: Direct Evidence from Large U.S. Supermarket Chains," Quarterly Journal of Economics, 113: 791-825, 1997.

[20] Lorenzo, Fernando, Diego Aboal and Rosa Osimani "The Elasticity of Substitution in Demand for Non-tradable Goods in Uruguay" mimeo, InterAmerican Development Bank Research Project, 2003.

[21] Neumeyer, Pablo Andrés and Perri, Fabrizio "Business Cycles in Emerging Economies: The Role of Interest Rates," forthcoming, Journal of Monetary Economics, 2005.

[22] Stockman, Alan C. and Linda L. Tesar "Tastes and Technology in a TwoCountry Model of the Business Cycle: Explaining International Comovements"' The American Economic Review, 85: 168-185, 1995.

[23] Zbaracki, Mark J., Mark Ritson, Daniel Levy, Shantanu Dutta, and Mark Bergen, "Managerial and Customer Dimensions of the Costs of Price Adjustment: Direct Evidence From Industrial Markets," Review of Economics and Statistics, 86: 514-533, 2004. 
Table 1: Benchmark Calibration, Parameter Values

\section{Common Parameters}

Distribution Margin, percent

Elasticity of labor supply

Elasticity of subst. in consumpt. between tradables and nontradables

Pre-devaluation markup

$50, \phi=1$

$4, \theta=0.25$

$0.4, \rho=0.4$

$20, \mu=1.2$

\section{Country Specific Parameters}

Share of tradable goods in CPI (inclusive of distribution costs), percent Foreign distribution margin, percent

Elasticity of demand for exports

Share of exports in GDP, percent

Level parameter, export production function

Level parameter, desutility of labor

\section{Korea}

$40, v=0.31$

$50, \phi^{*}=0.21$

$\gamma=2.53$

$32,(1+r) a_{0}=-0.93$

$A^{X}=19.6$

$B=0.44$
Uruguay

$40, v=0.31$

$50, \phi^{*}=0.43$

$\gamma=4.16$

$18,(1+r) a_{0}=0.11$

$A^{X}=3.72$

$B=0.46$
UK

$40, v=0.31$

$50, \phi^{*}=0.24$

$\gamma=2.67$

$23,(1+r) a_{0}=-0.27$

$A^{X}=13.62$

$B=0.41$ 
Table 2: Prices and Quantities in Korea One Year after Devaluation

\begin{tabular}{|c|c|c|c|c|c|}
\hline & 1 & 2 & 3 & 4 & 5 \\
\hline & \multicolumn{4}{|c|}{ Model } & \multirow{2}{*}{$\begin{array}{c}\text { Data } \\
\text { Selected } \\
\text { Variables }\end{array}$} \\
\hline & $\begin{array}{l}\text { Expansionary } \\
\text { Flexible Prices }\end{array}$ & $\begin{array}{l}\text { Expansionary } \\
\text { Sticky Prices }\end{array}$ & $\begin{array}{l}\text { Contractionary } \\
\text { Flexible Prices }\end{array}$ & $\begin{array}{c}\text { Contractionary } \\
\text { Sticky Prices }\end{array}$ & \\
\hline \multicolumn{6}{|l|}{ Prices (log percent change) } \\
\hline Nominal Exchange Rate & 37.3 & 37.3 & 37.3 & 37.3 & 37.3 \\
\hline Real Exchange Rate & 0.0 & -28.6 & -14.2 & -28.6 & -30.4 \\
\hline Consumer Price Index & 37.3 & 8.7 & 23.1 & 8.7 & 6.6 \\
\hline Nontradable Good & 37.3 & 0.0 & 19.3 & 0.0 & 5.1 \\
\hline Tradable Good & 37.3 & 20.4 & 28.7 & 20.4 & \\
\hline Export Price & 37.3 & 28.9 & 31.4 & 27.5 & \\
\hline Nominal Wage & 37.3 & 10.9 & 19.3 & 5.9 & \\
\hline \multicolumn{6}{|l|}{ Quantities (log percent change) } \\
\hline Total employment & 0.0 & 9.9 & -15.3 & -10.1 & \\
\hline Export employment & 0.0 & 10.4 & 7.3 & 12.1 & \\
\hline Exports & 0.0 & 10.4 & 7.3 & 12.1 & 12.0 \\
\hline Consumption & 0.0 & 8.5 & -19.0 & -14.5 & -14.4 \\
\hline Consumption of Tradable Good & 0.0 & 3.7 & -21.2 & -19.3 & \\
\hline Consumption of Nontradable Good & 0.0 & 9.9 & -18.4 & -13.1 & \\
\hline \multicolumn{6}{|l|}{ Incentives to Change Prices (levels) } \\
\hline Post-devaluation markup, stayers & & 7.6 & & 13.1 & \\
\hline Change in optimal price for deviator (K) & & 4.5 & & 0.0 & \\
\hline Optimal markup for deviator (K) & & 12.5 & & 13.1 & \\
\hline
\end{tabular}




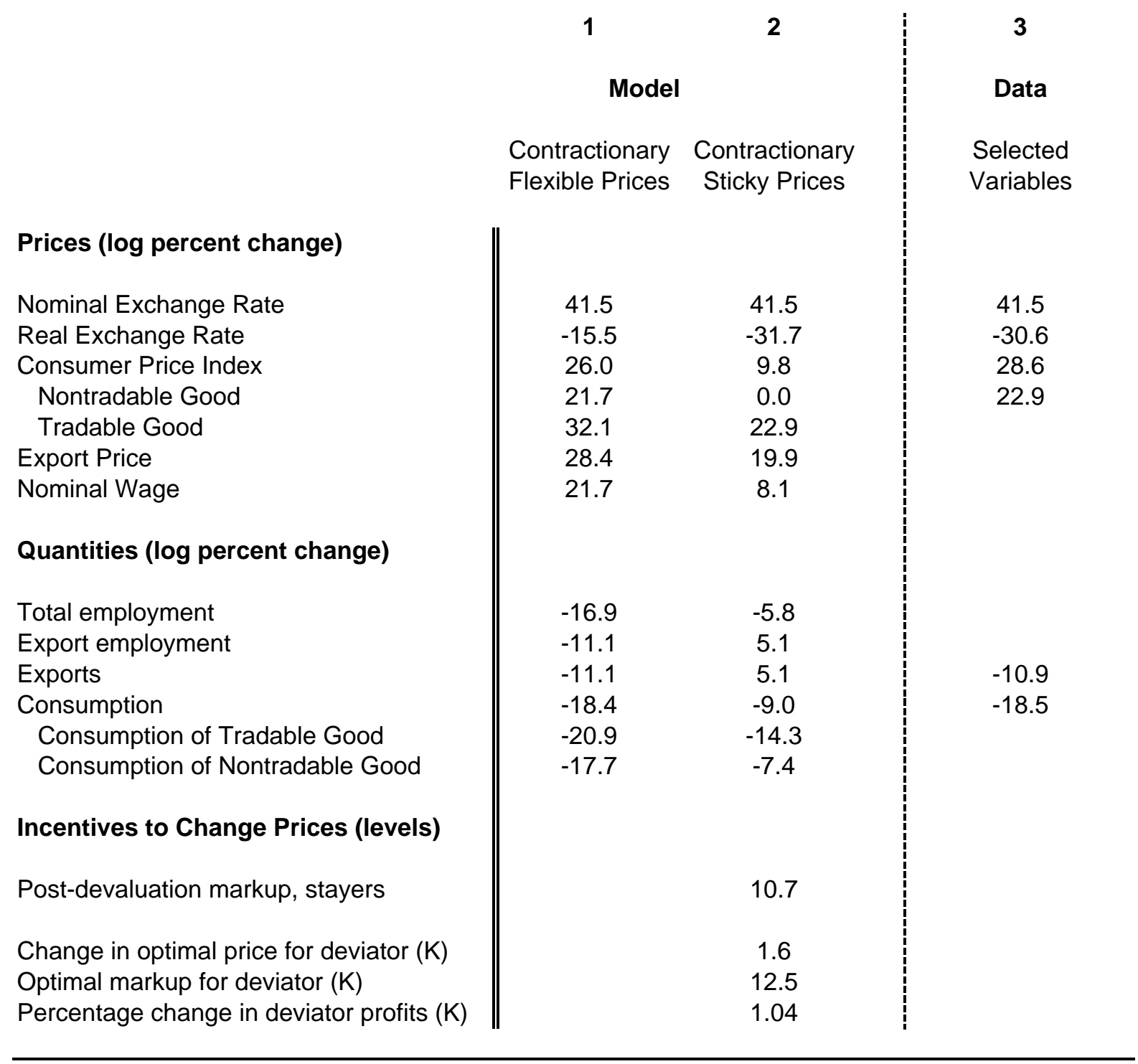




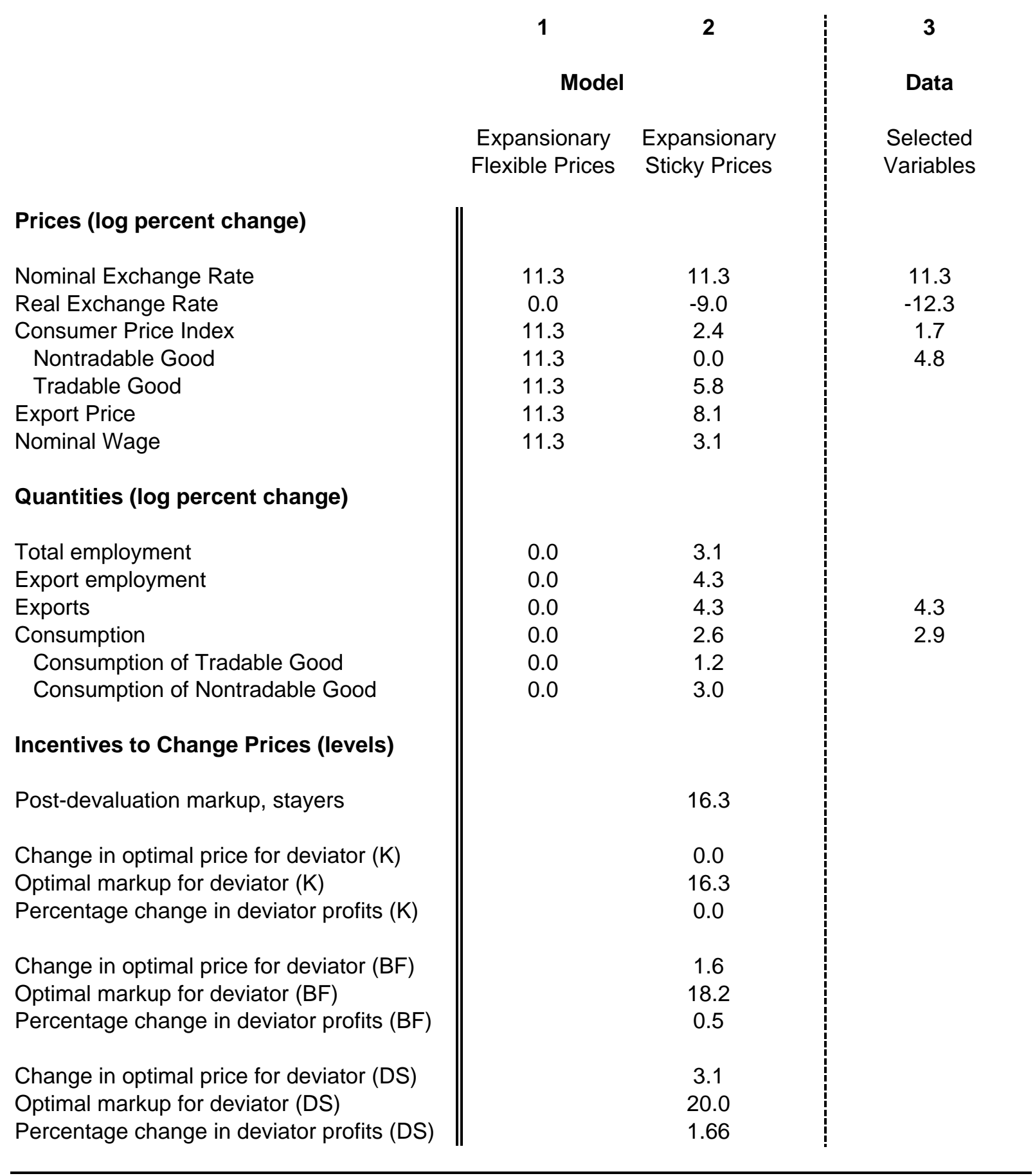


Table 5: The Role of Different Margins in the Model

\begin{tabular}{|c|c|c|c|c|c|}
\hline & 1 & 2 & 3 & 4 & 5 \\
\hline & $\begin{array}{l}\text { Benchmark } \\
\text { Expansionary }\end{array}$ & $\begin{array}{c}\text { Foreign } \\
\text { Distribution } \\
\text { Margin = 0\% }\end{array}$ & $\begin{array}{l}\text { Share of Traded } \\
\text { Goods in CPI } \\
25 \%\end{array}$ & $\rho=1$ & $\begin{array}{c}\text { Domestic } \\
\text { Distribution } \\
\text { Margin }=0 \%\end{array}$ \\
\hline \multicolumn{6}{|l|}{ Prices (log percent change) } \\
\hline Nominal Exchange Rate & 11.3 & 11.3 & 11.3 & 11.3 & 11.3 \\
\hline Real Exchange Rate & -9.0 & -9.0 & -9.8 & -9.0 & -6.6 \\
\hline Consumer Price Index & 2.4 & 2.4 & 1.5 & 2.4 & 4.7 \\
\hline Nontradable Good & 0.0 & 0.0 & 0.0 & 0.0 & 0.0 \\
\hline Tradable Good & 5.8 & 5.8 & 5.8 & 5.8 & 11.3 \\
\hline Export Price & 8.1 & 5.7 & 7.9 & 8.3 & 9.1 \\
\hline Nominal Wage & 3.1 & 5.7 & 2.6 & 3.7 & 5.8 \\
\hline \multicolumn{6}{|l|}{ Quantities (log percent change) } \\
\hline Total employment & 3.1 & 13.3 & 4.3 & 5.4 & 4.7 \\
\hline Export employment & 4.3 & 15.1 & 4.5 & 4.0 & 2.9 \\
\hline Exports & 4.3 & 15.1 & 4.5 & 4.0 & 2.9 \\
\hline Consumption & 2.6 & 12.6 & 4.0 & 4.7 & 3.0 \\
\hline Consumption of Tradable Good & 1.2 & 11.2 & 2.3 & 1.2 & 0.3 \\
\hline Consumption of Nontradable Good & 3.0 & 12.9 & 4.3 & 5.6 & 4.9 \\
\hline \multicolumn{6}{|l|}{ Incentives to Change Prices (levels) } \\
\hline Post-devaluation markup, stayers & 16.3 & 13.4 & 17.0 & 15.7 & 13.2 \\
\hline Change in optimal price for deviator (BF) & 1.6 & 4.1 & 1.0 & 2.1 & 4.2 \\
\hline Optimal markup for deviator (BF) & 18.2 & 18.2 & 18.2 & 18.2 & 18.2 \\
\hline \multirow[t]{5}{*}{ Percentage change in deviator profits (BF) } & 0.48 & 3.69 & 0.19 & 0.90 & 3.92 \\
\hline & Column 6 & Column 7 & Column 8 & & \\
\hline & Elasticity of & Share of & Labor Supply & & \\
\hline & Demand for & Exports in GDP & Elasticity & & \\
\hline & Exports $=3.7$ & $=10 \%$ & 1 & & \\
\hline \multicolumn{6}{|l|}{ Prices (log percent change) } \\
\hline Nominal Exchange Rate & 11.3 & 11.3 & 11.3 & & \\
\hline Real Exchange Rate & -9.0 & -9.0 & -9.0 & & \\
\hline Consumer Price Index & 2.4 & 2.4 & 2.4 & & \\
\hline Nontradable Good & 0.0 & 0.0 & 0.0 & & \\
\hline Tradable Good & 5.8 & 5.8 & 5.8 & & \\
\hline Export Price & 6.8 & 8.0 & 8.9 & & \\
\hline Nominal Wage & 4.0 & 2.9 & 5.1 & & \\
\hline \multicolumn{6}{|l|}{ Quantities (log percent change) } \\
\hline Total employment & 6.5 & 2.3 & 2.8 & & \\
\hline Export employment & 8.2 & 4.4 & 3.3 & & \\
\hline Exports & 8.2 & 4.4 & 3.3 & & \\
\hline Consumption & 5.8 & 1.9 & 2.3 & & \\
\hline Consumption of Tradable Good & 4.4 & 0.5 & 1.0 & & \\
\hline Consumption of Nontradable Good & 6.2 & 2.2 & 2.7 & & \\
\hline \multicolumn{6}{|l|}{ Incentives to Change Prices (levels) } \\
\hline Post-devaluation markup, stayers & 15.3 & 16.5 & 14.0 & & \\
\hline Change in optimal price for deviator (BF) & 2.4 & 1.4 & 3.6 & & \\
\hline Optimal markup for deviator (BF) & 18.2 & 18.2 & 18.2 & & \\
\hline Percentage change in deviator profits (BF) & 1.16 & 0.36 & 2.65 & & \\
\hline
\end{tabular}


1

Flexible Prices

0.0

$-14.2$

$-14.2$

$-18.0$

$-8.6$

$-5.9$

$-18.0$

Quantities (log percent change)

Total employment

Export employment

Exports

Consumption

Consumption of Tradable Good

Consumption of Nontradable Good

Incentives to Change Prices (levels)

Post-devaluation markup, stayers

Change in optimal price for deviator $(\mathrm{K})$

Optimal markup for deviator (K)

Percentage change in deviator profits $(\mathrm{K})$
$-15.3$

7.3

7.3

$-19.0$

$-21.2$

$-18.4$

1.0

0.0

0.0

0.00
2

3

Sticky Prices Sticky Prices

(No Devaluation) (With Devaluation)
0.0

0.0

0.0

0.0

0.0

$-1.7$

$-5.1$

$-20.5$

2.2

2.2

$-23.6$

$-23.6$

$-23.6$

26.3

0.0

26.3

0.00
37.3

$-28.6$

8.7

0.0

20.4

27.5

5.9

$-10.1$

12.1

12.1

$-14.5$

$-19.3$

$-13.1$

13.1

0.0

13.1

0.00 